\title{
UPAYA MENINGKATKAN HASIL BELAJAR KOGNITIF SISWA PADA MATA PELAJARAN IPA KELAS VIII.5 SMPN 8 TARAKAN MELALUI PENERAPAN MODEL PEMBELAJARAN PBL (PROBLEM BASED LEARNING)
}

\section{The Efforts to Improve Students' Science Cognitive Learning Outcomes At VIII.5 Grade In SMPN 8 Tarakan Through The Application Of Problem Based Learning Model}

\author{
Aidil Adhani ${ }^{\mathrm{a}^{*}}$, Mahatir Muhammad ${ }^{\mathrm{b}}$
}

a,b Prodi Pendidikan Biologi/Pendidikan Biologi/Universitas Borneo Tarakan, Tarakan, Kalimantan Utara, Indonesia

"Corresponding author: J1. Amal Lama, Tarakan Timur, Tarakan, Kalimantan Utara, 77123, Indonesia. E-mail: adhani89@gmail.com

\begin{abstract}
Abstrak
Pembelajaran merupakan proses yang melibatkan peserta didik dan pendidik dalam sebuah lingkungan belajar. Proses tersebut adalah kegiatan yang sudah direncanakan oleh pendidik untuk membelajarkan peserta didiknya melalui sebuah model dengan memanfatkan media maupun sumber belajar yang bervariasi. Berdasarkan hasil observasi dan wawancara yang dilakukan dengan guru IPA di SMP Negeri 8 Tarakan, hasil belajar kognitif siswa kelas VIII.5 masih rendah. Upaya yang dilakukan oleh peneliti untuk meningkatkan hasil belajar peserta didik adalah dengan merancang pembelajaran yang mampu mengaktifkan proses-proses kognisi peserta didik dengan baik. Perencanaan pembelajaran secara utuh dapat dilakukan dengan penerapan model pembelajaran tertentu secara tepat, salah satunya dengan model PBL (Problem Based Learning). Tujuan dari penelitian iniyaitu untuk meningkatkan hasil belajar kognitif siswa pada mata pelajatran IPA kelas VIII 5 SMPN 8 Tarakan melalui penerapan model PBL. Teknik pengumpulan data yang digunakan pada penelitian ini adalah observasi dan tes. Data yang dikumpulkan adalah data tentang hasil belajar kognitif siswa. Analisis deskriptif komparatif adalah membandingkan data nilai pretest dan posstest pada siklus I dan siklus II. Hasil penelitian menunjukkan bahwa terjadi peningkatan ketuntasan hasil belajar siswa dari siklus I sebesar 73,33\% menjadi 90\% pada siklus II dengan model pembelajaran PBL.
\end{abstract}

\section{Kata kunci}

Hasil belajar, Kognitif, PBL.

\section{Abstract}

Learning is a process that involves students and teachers in a learning environment. The process is an activity that has been planned by teacher to teach their students through a model by utilizing varied media and learning resources. Based on the results of observations and interviews conducted with science teachers at SMP Negeri 8 Tarakan, cognitive learning outcomes of VIII.5 grade students are still low. The effort made by researchers to improve student learning outcomes is to design learning that able to activate the students'cognitive 


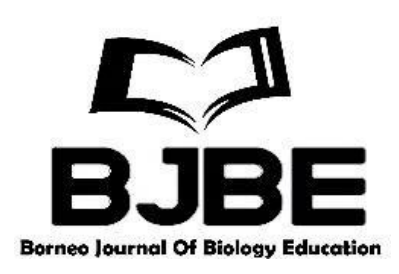

processes well. Learning planning as a whole can be done by applying certain learning models appropriately, one of them with PBL (Problem Based Learning) models. The purpose of this study is to improve students' cognitive learning outcomes in the science class VIII5 grade at SMP Negeri 8 Tarakan through the application of the PBL model. Data collection techniques used in this study were observation and tests. The data collected is data about student cognitive learning outcomes. Comparative descriptive analysis compares the pretest and posttest value data in cycle I and cycle II. The results showed that there was an increase in completeness of student learning outcomes from the first cycle by $73.33 \%$ to $90 \%$ in the second cycle with PBL learning models.

Keywords

Learning outcomes, cognitive, PBL.

\section{Pendahuluan}

Pendidikan memegang peranan penting dalam setiap langkah perubahan ke arah yang lebih baik. Secara umum, pendidikan merupakan upaya sadar dan terencana yang dilakukan untuk mempersiapkan sumberdaya manusia yang berkualitas ataupun memperbaiki kualitas sumber daya manusia itu sendiri. Esensi dari pendidikan tersebut dapat tercapai melalui proses-proses yang dilakukan dalam lingkup pendidikan itu sendiri, seperti proses pembelajaran. Pembelajaran merupakan proses yang melibatkan peserta didik dan pendidik dalam sebuah lingkungan belajar. Proses tersebut adalah kegiatan yang sudah direncanakan oleh pendidik untuk membelajarkan peserta didiknya melalui sebuah model dengan memanfatkan media maupun sumber belajar yang bervariasi.

Berdasarkan hasil observasi dan wawancara yang dilakukan dengan guru IPA di SMP Negeri 8 Tarakan, rata-rata siswa kelas VIII masih tergolong pasif dalam pembelajaran. Respon terhadap pertanyaan ataupun antusiasme dalam mengikuti kegiatan belajar mengajar masih dapat digolongkan dalam aktivitas belajar kategori rendah. Hal tersebut mempengaruhi hasil akhir dari proses pembelajaran. Hasil belajar yang diperoleh menunjukkan bahwa masih ada siswa yang belum memenuhi kriteria ketuntasan minimal yakni 67. Berdasarkan kondisi tersebut, maka peneliti ingin berupaya untuk meningkatkan hasil belajar kognitif pada siswa kelas VIII, khususnya kelas VIII.5 yang memiliki rata-rata nilai terendah dari total 6 kelas VIII di SMPN 8 Tarakan.

Upaya yang dilakukan oleh peneliti untuk meningkatkan hasil belajar peserta didik adalah dengan merancang pembelajaran yang mampu mengaktifkan proses-proses kognisi peserta didik dengan baik. Perencanaan pembelajaran secara utuh dapat dilakukan dengan penerapan model pembelajaran tertentu secara tepat. Model pembelajaran itu sendiri merupakan gambaran umum dari kegiatan pembelajaran yang dilaksanakan oleh guru dari awal hingga pembelajaran berakhir. Di dalam sebuah model, akan ditemui adanya pendekatan, strategi, metode, maupun teknik pembelajaran yang dirangkai menjadi satu kesatuan untuk mencapai tujuan pembelajaran yang telah ditetapkan. Salah satu model pembelajaran yang dianggap mampu untuk memaksimal proses kognisi peserta didik adalah model pembelajaran PBL (Problem Based Learning).

PBL (Problem Based Learning) merupakan salah satu model pembelajaran yang dianjurkan dalam kurikulum 2013. Model tersebut memfasilitasi siswa untuk dapat menerapkan pendekatan saintifik dalam setiap proses pembelajaran yang dilalui oleh siswa. 


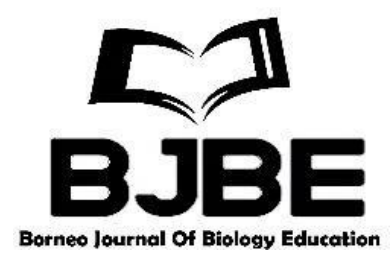

Ciri khas dari model ini adalah adanya pemberian masalah yang bersifat kontekstual dari guru kepada siswa. Permasalahan tersebut diharapkan dapat mengaktifkan proses kognisi siswa dan mengarahkan pola pikir siswa untuk lebih kreatif dalam pemecahan masalah yang berdasar pada konsep yang tepat. Berdasarkan sudut pandang PBL yakni tujuan pembelajaran dapat dicapai jika kegiatan yang direncanakan dipusatkan pada tugas-tugas atau permasalahan yang sifatnya konkrit dan dipresentasikan dalam sebuah konteks. Cara tersebut bertujuan agar siswa memilki pengalaman sebagaiamana nantinya mereka hadapi di kehidupan sehari-hari. Pengalaman tersebut sangat penting karena pembelajaran yang efektif dimulai dari pengalaman konkrit.

PBL merupakan sebuah model pembelajaran yang didasarkan pada prinsip bahwa masalah dapat digunakan sebagai titik awal untuk mendapatkan serta mengintegrasikan pengetahuan baru. Menurut Trianto (2009) karakteristik model PBL yaitu: (a) adanya pengajuan pertanyaan atau masalah, (b) berfokus pada keterkaitan antar disiplin, (c) penyelidikan autentik, (d) menghasilkan produk atau karya dan mempresentasikannya, dan

(e) kerja sama. Berdasarkan hal tersebut, maka peneliti tertarik untuk menerapkan model pembelajaran PBL sebagai upaya untuk meningkatkan hasil belajar kognitif siswa kelas VIII 5 SMPN 8 Tarakan.

\section{Material dan metode}

Jenis penelitian yang digunakan adalah penelitian tindakan kelas (PTK) yang dilaksanakan oleh guru di dalam kelas. Penelitian Tindakan Kelas lebih bertujuan untuk memperbaiki kinerja, sifatnya kontekstual dan hasilnya tidak untuk digeneralisasi. Namun demikian hasil penelitian tindakan dapat saja diterapkan oleh orang lain yang mempunyai latar yang mirip dengan yang dimiliki peneliti. Karasteristik yang khas dari penelitian tindakan kelas ini yakni tindakan-tindakan yang khas (aksi) yang dilaksanakan secara berulang-ulang untuk memperbaiki proses belajar mengajar di kelas.

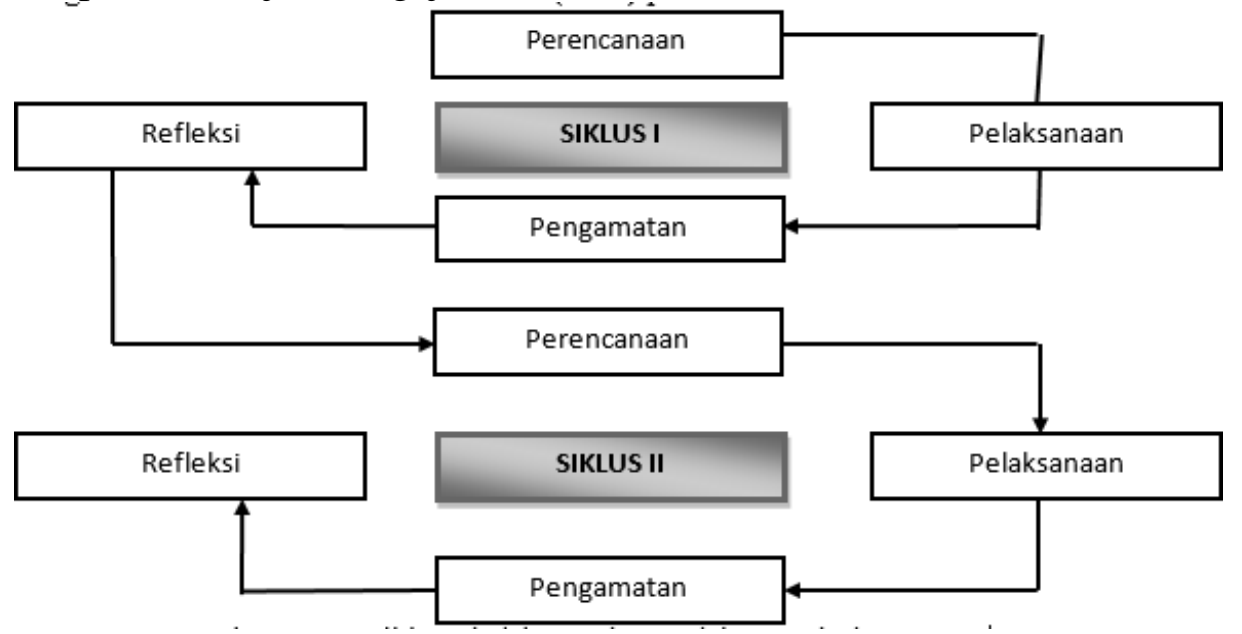

Gambar 1. Penelitian Tindakan Kelas Model Kemmis dan Taggart (Arikunto, 2010)

Instrumen penelitian merupakan alat yang dipergunakan peneliti dan observer secara kolaborasi untuk mengumpulkan data atau informasi tentang pelaksanaan tindakan. Adapun instrumen yang digunakan dalam penelitian ini adalah sebagai berikut.

1. Lembar Observasi Keterlaksanaan model pembelajaran PBL. Lembar observasi ini digunakan untuk mengetahui apakah proses pembelajaran benar-benar berjalan sesuai 


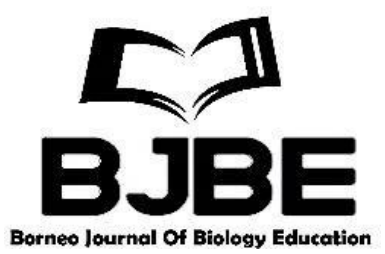

dengan tahap-tahap model pembelajaran PBL. Pengamatan yang dilakukan meliputi aktivitas Guru dan aktivitas Siswa

2. Soal Tes Hasil Belajar yang dikembangkan oleh peneliti sesuai dengan karakteristik model PBL untuk mengukur hasil belajar pada aspek kognitif. Soal tersebut merupakan soal uraian berjumlah 6 nomor. Target ketuntasan yang diharapkan oleh peneliti adalah $70 \%$ siswa memiliki nilai $\geq 67$.

Teknik pengumpulan data yang digunakan pada penelitian ini adalah observasi dan tes. Data yang dikumpulkan adalah data tentang hasil belajar kognitif siswa. Setelah data dalam penelitian tindakan kelas ini diperoleh maka selanjutnya dilakukan analisis data. Analisis deskriptif komparatif adalah membandingkan data nilai awal tes dengan data siklus I dan siklus II. Data hasil observasi merupakan data kualitatif. Analisis data kualitatif dilakukan dengan membandingkan data hasil observasi antar siklus. Analisis nilai dilakukan dengan menggunakan pendekatan analisis deskriptif berupa paparan data dalam bentuk angka agar dapat memberikan gambaran secara teratur, ringkas dan jelas mengenai gejala, peristiwa atau keadaan sehingga dapat ditarik pengertian atau makna tertentu (Anas, 2008).

\section{Hasil dan Diskusi}

Pengambilan data penelitian yang dilakukan pada siklus I dan siklus II meliputi data kuantitatif dan data kualitatif. Data kuantitatif dalam penelitian yaitu berupa data hasil belajar siswa untuk melihat keterampilan berpikir siswa. Sedangkan data kualitatif dalam penelitian yaitu berupa hasil pengamatan terhadap aktivitas siswa, aktivitas guru saat melaksanakan pembelajaran dan kemampuan guru dalam merancang RPP pada siklus I. Pada deskripsi data siklus I dan II akan diuraikan mengenai: (1) data hasil pengamatan aktivitas guru, (2) data hasil pengamatan aktivitas belajar siswa, (3) data hasil belajar siswa, (4) data ketuntasan belajar.

\section{1) Aktivitas Guru}

Pada tahap pengamatan aktivitas mengajar pada pembelajaran IPA menggunakan model PBL di kelas VIII.5 SMPN 8 Tarakan diperoleh melalui lembar pengamatan berdasarkan kriteria penilaian yang telah ditetapkan. Berikut data hasil pengamatan aktivitas guru dalam pelaksanaan pembelajaran pada siklus I dan II disajikan pada Tabel 1 dan 2 berikut.

Tabel 1. Aktivitas guru berdasarkan model PBL siklus I

\begin{tabular}{llccc}
\hline \multirow{2}{*}{ No } & \multicolumn{1}{c}{ Aspek yang diamati } & \multicolumn{2}{c}{$\begin{array}{c}\text { Rata-rata Skor (\%) } \\
\text { P1 }\end{array}$} & $\begin{array}{c}\text { P2 } \\
\text { Rata-rata skor } \\
\text { P1 dan P2 (\%) }\end{array}$ \\
\hline 1 & $\begin{array}{l}\text { Mengorganisasi siswa pada masalah } \\
2\end{array}$ & 76.5 & 85 & 80.75 \\
$\begin{array}{l}\text { Mengorganisasikan siswa untuk } \\
\text { belajar }\end{array}$ & 80 & 87.5 & 83.75 \\
\multirow{2}{*}{3} & $\begin{array}{l}\text { Membimbing penyelidikan individu } \\
\text { dan kelompok }\end{array}$ & 70 & 77.5 & 73.75 \\
\multirow{2}{*}{$\begin{array}{l}\text { Mengembangkan dan menyajikan } \\
\text { hasil karya }\end{array}$} & 70 & 75 & 72.5 \\
\multirow{2}{*}{5} & $\begin{array}{l}\text { Menganalisa dan mengevaluasi } \\
\text { proses pemecahan masalah }\end{array}$ & 78 & 87.5 & 82.75 \\
\hline Jumlah Skor & $\mathbf{3 7 4 . 5}$ & $\mathbf{4 1 2 . 5}$ & $\mathbf{3 9 3 . 5}$ \\
\hline Rata-rata Skor & $\mathbf{7 4 . 9}$ & $\mathbf{8 2 . 5}$ & $\mathbf{7 8 . 7}$ \\
\hline Kategori & Baik & Baik Sekali & Baik \\
\hline
\end{tabular}




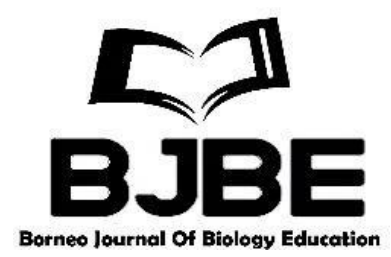

Tabel 2. Aktivitas guru berdasarkan model PBL siklus II

\begin{tabular}{llccc}
\hline \multirow{2}{*}{ No } & \multicolumn{1}{c}{ Aspek yang diamati } & \multicolumn{2}{c}{ Rata-rata Skor (\%) } & $\begin{array}{c}\text { Rata-rata skor } \\
\text { P1 dan P2 (\%) }\end{array}$ \\
\hline 1 & Mengorganisasi siswa pada masalah & 80 & 85 & 82.5 \\
2 & $\begin{array}{l}\text { Mengorganisasikan siswa untuk } \\
\text { belajar }\end{array}$ & 80 & 87.5 & 83.75 \\
\multirow{2}{*}{3} & $\begin{array}{l}\text { Membimbing penyelidikan individu } \\
\text { dan kelompok }\end{array}$ & 75 & 80 & 77.5 \\
\multirow{2}{*}{4} & $\begin{array}{l}\text { Mengembangkan dan menyajikan } \\
\text { hasil karya }\end{array}$ & 80 & 87.5 & 83.75 \\
5 & $\begin{array}{l}\text { Menganalisa dan mengevaluasi } \\
\text { proses pemecahan masalah }\end{array}$ & 85 & 90 & 87.5 \\
\hline & Jumlah Skor & $\mathbf{4 0 0}$ & $\mathbf{4 3 0}$ & $\mathbf{4 1 5}$ \\
\hline & Rata-rata Skor & $\mathbf{8 0}$ & $\mathbf{8 6}$ & $\mathbf{8 3}$ \\
\hline & Kategori & Baik & Baik Sekali & Baik Sekali \\
\hline
\end{tabular}

Pada siklus I, terlihat bahwa aktivitas guru selama proses pembelajaran mencapai ratarata $74,9 \%$ (kategori baik) pada pertemuan pertama dan $82,5 \%$ (kategori baik sekali) pada pertemuan kedua. Data tersebut menunjukkan adanya peningkatan persentase keterlaksanaan sintaks pembelajaran oleh guru. Meskipun telah terjadi peningkatan aktivitas guru pada siklus I, peneliti tetap melanjutkan ke siklus II dengan dua pertemuan. Rata-rata skor pada pertemuan pertama sebesar $80 \%$ (kategori baik sekali) dan meningkat pada pertemuan kedua menjadi $86 \%$ (kategori baik sekali). Secara umum, peningkatan terjadi dari siklus I ke siklus II, rata-rata skor pertemuan pertama dan kedua pada siklus I sebesar 78,7\% (kategori baik) dan meningkat menjadi 83\% (kategori baik sekali) pada siklus II.

\section{2) Aktivitas Siswa}

Aktivitas siswa merupakan proses yang terjadi dalam kegiatan belajar mengajar yang diamati berdasarkan lembar pengamatan yang dilakukan oleh observer pada setiap pertemuan. Berikut data hasil pengamatan aktivitas siswa dalam pelaksanaan pembelajaran pada siklus I dan II disajikan pada Tabel 3 dan 4.

Tabel 3. Aktivitas siswa berdasakan model PBL siklus I

\begin{tabular}{clccc}
\hline \multirow{2}{*}{ No } & \multicolumn{1}{c}{ Aspek yang diamati } & \multicolumn{2}{c}{ Rata-rata Skor (\%) } & Rata-rata skor \\
& P1 & P2 & P1 dan P2 (\%) \\
\hline 1 & $\begin{array}{l}\text { Menyimak penjelasan guru } \\
\text { mengenai tujuan pembelajaran }\end{array}$ & 70 & 76.7 & 73.35 \\
& $\begin{array}{l}\text { logistik yang dibutuhkan, serta } \\
\text { termotivasi menentukan pemecahan } \\
\text { masalah sesuai topic }\end{array}$ & & & \\
2 & $\begin{array}{l}\text { Mengorganisasikan tugas belajar } \\
\text { yang berhubungan dengan masalah } \\
\text { yang diberikan guru }\end{array}$ & 80 & 87.5 & 83.75 \\
3 & $\begin{array}{l}\text { Mengumpulkan infomasi yang } \\
\text { sesuai, melaksanakan eksprimen } \\
\text { untuk mendapatkan penjelasan dan } \\
\text { pemecahan masalah }\end{array}$ & 70 & 77.5 & 73.75 \\
& & &
\end{tabular}




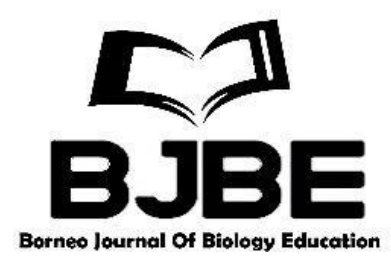

4 Merencanakan dan menyiapkan

karya yang sesuai (seperti laporan, video, dan model) serta berbagi tugas dalam kelompok

5 Melakukan refleksi atau evaluasi terhadap penyelidikan yang dilakukan dan proses-proses yang mereka gunakan

\begin{tabular}{lccc}
\hline Jumlah Skor & 365 & 404.2 & 384.6 \\
\hline Rata-rata Skor & 73 & 80.84 & 76.92 \\
\hline Kategori & Baik & Baik Sekali & Baik \\
\hline
\end{tabular}

Berdasarkan data pada Tabel 3 di atas dapat dilihat bahwa aktivitas siswa pada siklus I rata-rata setiap pertemuan mengalami peningkatan dari pertemuan pertama ke pertemuan kedua. Pada pertemuan pertama diperoleh hasil sebesar 73\% (kategori baik) dan pertemuan kedua sebesar $80,84 \%$ (kategori baik sekali), dengan rata-rata kedua pertemuan mencapai 76,92\% (kategori baik).

Tabel. 4. Aktivitas siswa berdasarkan model PBL siklus II

\begin{tabular}{|c|c|c|c|c|}
\hline \multirow{2}{*}{ No } & \multirow{2}{*}{ Aspek yang diamati } & \multicolumn{2}{|c|}{ Rata-rata Skor (\%) } & \multirow{2}{*}{$\begin{array}{l}\text { Rata-rata skor } \\
\text { P1 dan P2 (\%) }\end{array}$} \\
\hline & & P1 & $\mathbf{P 2}$ & \\
\hline 1 & $\begin{array}{l}\text { Menyimak penjelasan guru } \\
\text { mengenai tujuan pembelajaran, } \\
\text { logistik yang dibutuhkan, serta } \\
\text { termotivasi menentukan pemecahan } \\
\text { masalah sesuai topik }\end{array}$ & 77.5 & 87.5 & 82.5 \\
\hline 2 & $\begin{array}{l}\text { Mengorganisasikan tugas belajar } \\
\text { yang berhubungan dengan masalah } \\
\text { yang diberikan guru }\end{array}$ & 80 & 87.5 & 83.75 \\
\hline 3 & $\begin{array}{l}\text { Mengumpulkan infomasi yang } \\
\text { sesuai, melaksanakan eksprimen } \\
\text { untuk mendapatkan penjelasan dan } \\
\text { pemecahan masalah }\end{array}$ & 70 & 75 & 72.5 \\
\hline 4 & $\begin{array}{l}\text { Merencanakan dan menyiapkan } \\
\text { karya yang sesuai (seperti laporan, } \\
\text { video, dan model) serta berbagi } \\
\text { tugas dalam kelompok }\end{array}$ & 76.5 & 80 & 78.25 \\
\hline \multirow[t]{4}{*}{5} & $\begin{array}{l}\text { Melakukan refleksi atau evaluasi } \\
\text { terhadap penyelidikan yang } \\
\text { dilakukan dan proses-proses yang } \\
\text { mereka gunakan }\end{array}$ & 78 & 87.5 & 82.75 \\
\hline & Jumlah Skor & 382 & 417.5 & 399.75 \\
\hline & Rata-rata Skor & 76.4 & 83.5 & 79.95 \\
\hline & Kategori & Baik & Baik Sekali & Baik \\
\hline
\end{tabular}

Pada siklus I, telah terjadi peningkatan aktivitas siswa dan dilanjutkan lagi ke siklus II. Berdasarkan data pada Tabel 4 di atas dapat dilihat bahwa rata-rata aktivitas siswa pada siklus II setiap pertemuan juga mengalami peningkatan dari pertemuan pertama ke pertemuan kedua. Pada pertemuan pertama diperoleh rata-rata sebesar 76,4\% (kategori baik) dan 


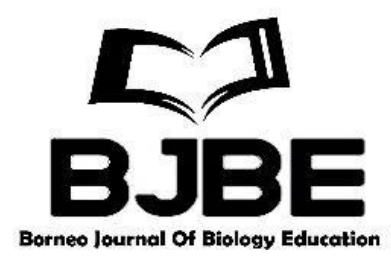

pertemuan kedua sebesar 83,5\% (kategori baik sekali), dengan rata-rata kedua pertemuan mencapai 79,95\% (kategori baik).

\section{3) Hasil Belajar Siswa}

Hasil belajar siswa pada materi sistem pencernaan (siklus I) dan materi zat aditif dan zat adiktif (siklus II) dengan menggunakan model PBL digunakan untuk mengetahui hasil belajar siswa siswa. Pada akhir siklus, guru memberikan soal tes hasil belajar berupa 6 butir soal berbentuk uraian. Data tes hasil belajar IPA siswa di kelas VIII.5 SMPN 8 Tarakan pada siklus I dan siklus II dapat dilihat pada Tabel 5 dan 6 berikut.

Tabel 5. Hasil belajar siswa siklus I

\begin{tabular}{cccc}
\hline No & Rentang Nilai & Jumlah Siswa & $\begin{array}{c}\text { Persentase } \\
(\boldsymbol{\%})\end{array}$ \\
\cline { 3 - 4 } 1 & $80-100$ & 14 & 46.7 \\
2 & $66-79$ & 9 & 30 \\
3 & $56-65$ & 0 & 0 \\
4 & $40-55$ & 5 & 16.6 \\
5 & $0-39$ & 2 & 6.7 \\
\hline & Jumlah & $\underline{\mathbf{3 0}}$ & $\underline{\mathbf{1 0 0}}$
\end{tabular}

Berdasarkan data hasil belajar siswa pada siklus I di atas, siswa yang memperoleh nilai antara 80-100 sebanyak 14 siswa dengan persentase 46,7\%, siswa yang memperoleh nilai antara 66-79 sebanyak 9 siswa dengan persentase 30\%, tidak ada siswa yang memperoleh nilai antara 56-65, siswa yang memperoleh nilai antara 40-55 sebanyak 5 siswa dengan persentase $16,6 \%$ dan siswa yang memperoleh nilai antara 0-39 sebanyak 2 siswa dengan persentase $6,7 \%$.

Tabel 6. Hasil belajar siswa siklus II

\begin{tabular}{lccc}
\hline No & Rentang Nilai & Jumlah Siswa & $\begin{array}{c}\text { Persentase } \\
(\mathbf{\%})\end{array}$ \\
1 & $80-100$ & 18 & 60 \\
2 & $66-79$ & 9 & 30 \\
3 & $56-65$ & 1 & 3.33 \\
4 & $40-55$ & 1 & 3.33 \\
5 & $0-39$ & 1 & 3.33 \\
\hline & Jumlah & $\underline{30}$ & $\underline{\mathbf{1 0 0}}$ \\
\cline { 2 - 3 }
\end{tabular}

Berdasarkan data hasil belajar siswa pada siklus II di atas, siswa yang memperoleh nilai antara 80-100 sebanyak 18 siswa dengan persentase 60\%, siswa yang memperoleh nilai antara 66-79 sebanyak 9 siswa dengan persentase 30\%, siswa yang memperoleh nilai antara 56-65, 40-55, 0-39 masing-masing sebanyak 1 siswa dengan persentase 33,33\%. Persentase ketuntasan hasil belajar IPA pada siklus I dan II disajikan pada Tabel 7 dan 8 berikut. 


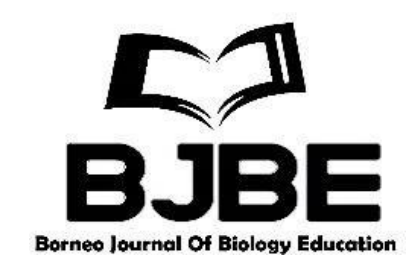

Tabel 7. Data ketuntasan siswa siklus I

\begin{tabular}{cccc}
\hline \multirow{2}{*}{ No } & Keterangan & $\begin{array}{c}\text { Jumlah } \\
\text { Siswa }\end{array}$ & $\begin{array}{c}\text { Ketuntasan } \\
(\mathbf{\%})\end{array}$ \\
\cline { 3 - 3 } 1 & Tuntas & 22 & 73.33 \\
2 & Tidak Tuntas & 8 & 26.67 \\
\hline & Jumlah & $\mathbf{3 0}$ & $\mathbf{1 0 0}$ \\
\hline
\end{tabular}

Tabel 8. Data ketuntasan siswa siklus II

\begin{tabular}{cccc}
\hline \multirow{2}{*}{ No } & \multirow{2}{*}{ Keterangan } & $\begin{array}{c}\text { Jumlah } \\
\text { Siswa }\end{array}$ & $\begin{array}{c}\text { Ketuntasan } \\
(\mathbf{\%})\end{array}$ \\
\cline { 3 - 3 } 1 & Tuntas & 27 & 90 \\
2 & Tidak Tuntas & 3 & 10 \\
\hline & Jumlah & $\mathbf{3 0}$ & $\mathbf{1 0 0}$ \\
\hline
\end{tabular}

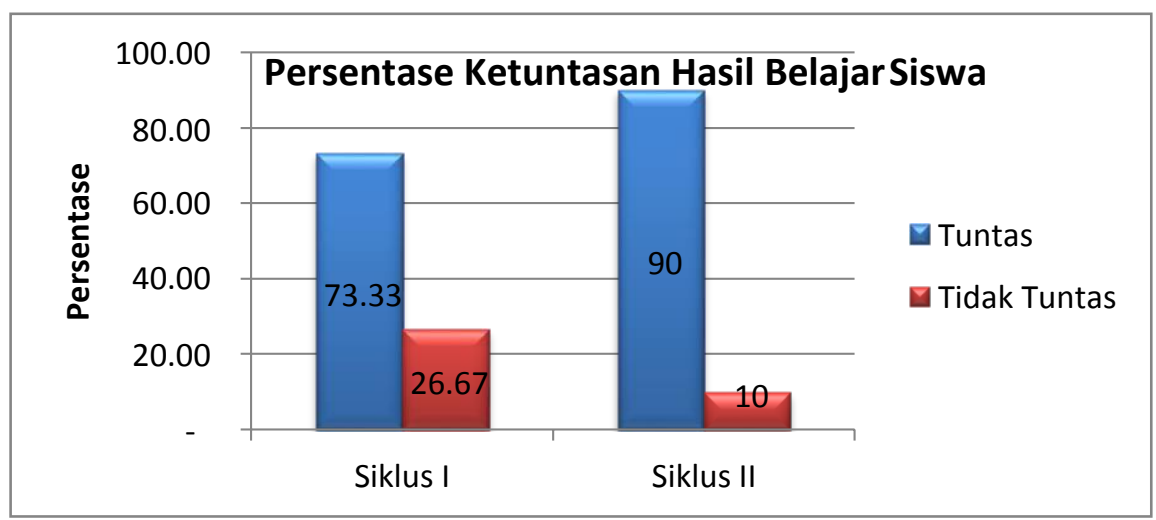

Gambar 2. Diagram persentase ketuntasan hasil belajar kognitif siswa

Berdasarkan hasil analisis tes hasil belajar pada materi pencernaan serta materi zat aditif dan adiktif, pada tes siklus II dapat disimpulkan bahwa dari total 30 siswa jumlah siswa yang tuntas adalah 27 siswa atau mencapai 90\%. Sedangkan siswa yang belum mencapai nilai ketuntasan hanya 3 siswa atau $10 \%$ dari total siswa di kelas VIII5. Data tersebut menunjukkan bahwa hanya tersisa 3 siswa dengan nilai yang belum mencapai KKM. Penelitian ini dianggap berhasil meningkatkan hasil belajar siswa karena lebih dari $70 \%$ siswa telah mencapai KKM yang telah ditetapkan, maka peneliti memutuskan untuk menghentikan siklus penelitian.

Tujuan umum penelitian ini adalah untuk meningkatkan kualitas pembelajaran IPA dalam aspek hasil belajar kognitif siswa kelas VIII5 di SMPN 8 Tarakan. Upaya untuk mencapai tujuan penelitian tersebut, peneliti menggunakan salah satu model pembelajaran yang dianggap mampu meningkatkan hasil belajar kognitif siswa. Model PBL (Problem Based Learning) yang digunakan pada kelas tersebut berhasil meningkatkan hasil belajar siswa hingga lebih dari $70 \%$ siswa dari total 30 siswa yang telah mencapai KKM. Faktor yang mempengaruhi peningkatan hasil belajar kognitif siswa yaitu aktivitas guru dalam pelaksanaan model PBL serta aktivitas siswa dalam mengikuti pembelajaran dengan model PBL.

Tugas utama seorang guru adalah menyelenggarakan pembelajaran yang baik dan berkualitas bagi siswa. Penerapan model pembelajaran PBL pada pembelajaran IPA memberikan masukan pada guru untuk menerapkan model yang berbasis pendekatan saintifik 


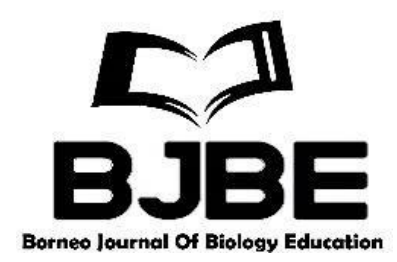

secara tepat. Penerapan model yang tepat dalam proses pembelajaran akan membantu guru menciptakan pembelajaran yang bermakna dan berpusat pada siswa. Selain itu, guru dapat menciptakan kegiatan pembelajaran yang menarik dan tidak membosankan.

Nuraini (2017) menyatakan bahwa model pembelajaran PBL menuntut siswa untuk membangun pengetahuan-pengetahuan siswa sendiri dengan memecahkan masalah yang siswa hadapi. Dalam pembelajaran siswa diorientasikan kedalam masalah, secara berkelompok siswa bersama-sama untuk mencari jalan keluar dalam masalah. Siswa bersama kelompok melakukan percobaan untuk dapat memecahkan masalah yang ada. Setelah siswa mampu memecahkan masalah siswa mempresentasikan hasil penelitian kelompok di depan kelas. Kelompok lain menanggapi saat ada temannya yang sedang presentasi. Guru di dalam kelas menjadi fasilitator jadi siswa yang mendominasi pembelajaran bukan pembelajaran berpusat pada guru. Pada akhir pembelajaran guru memberikan evaluasi untuk mengetahui sejauh mana siswa dapat memahami tentang materi yang dipelajari.

Hasil penelitian Abdullah dan Ridwan (2008) menyatakan model PBL dapat meningkatkan hasil belajar siswa salah satunya pada aspek kognitif. Aspek kognitif ini mencakup aktivitas mental (otak). Adanya masalah yang harus diselesaikan oleh siswa membuat siswa jadi aktif untuk melakukan aktivitas mental. Pengetahuan yang diperoleh dari aktivitas tersebut menjadi alat ukur peningkatan hasil belajar kognitif. Hal serupa dikemukakan oleh fauzan,dkk (2017), bahwa peningkatan hasil belajar terjadi karena dalam penerapan model PBL peserta didik lebih terlatih dalam memecahkan berbagai permasalahan sesuai dengan kemampuan melalui penyelidikan secara autentik. Model PBL ini memiliki gagasan bahwa pembelajaran akan lebih efektif jika kegiatan belajar mengajar dipusatkan pada aktivitas siswa. Aktivitas seperti pemberian permasalahan yang otentik dan relevan dengan kondisi lingkungan siswa membuat siswa memiliki pengalaman belajar yang lebih bermakna. Pengalaman belajar melalui keterlibatan langsung peserta didik akan membuat mereka semakin aktif dalam belajar. Keaktifan peserta didik sangat berpengaruh terhadap hasil belajar karena membuat mereka semakin paham tentang materi yang dipelajari. Peningkatan hasil belajar kognitif siswa tidak lepas dari kelebihan model PBL tersebut. Menurut Warsono dan Hariyanto (2012), kelebihan dari model PBL adalah siswa akan terbiasa menghadapi masalah dan merasa tertantang untuk menyelesaikan masalah.

\section{Kesimpulan}

Berdasarkan penelitian yang telah dilakukan dapat disimpulkan bahwa model pembelajaran PBL (Problem Based Learning) dapat meningkatkan hasil belajar siswa kelas VIII.5 pada mata pelajaran IPA. Hasil tersebut terlihat pada peningkatan persentase ketuntasan hasil belajar dari siklus I sebesar $73,33 \%$ menjadi $90 \%$ pada siklus II.

\section{Daftar Pustaka}

Abdullah, A.G dan Ridwan, T. (2008). Implementasi Problem Based Learning (PBL) pada Proses Pembelajaran di BPTP Bandung. Prosiding UPI. 1-10.

Arikunto, S. (2010). Dasar-Dasar Evaluasi Pendidikan. Jakarta: Bumi Aksara.

Fauzan, M., Gani, A., Syukri, M. (2017). Penerapan Model Problem Based Learning Pada Pembelajaran Materi Sistem Tata Surya Untuk Meningkatkan Hasil Belajar Siswa. Jurnal Pendidikan Sains Indonesia, 5 (10), 27-35. 


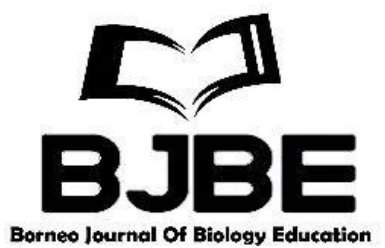

Nurani, F. (2017). Penggunaan Model Pembelajaran Problem Based Learning (PBL) untuk Meningkatkan Hasil Belajar IPA Siswa Kelas 5 SD. E-Jurnal Mitra Pendidikan, $1(4), 369-379$.

Trianto. (2009). Mendesain Model Pembelajaran Inovatif-Progresif. Jakarta: Kencana Prenada.

Warsono dan Hariyanto. (2012). Pembelajaran Aktif Teori dan Asesmen. Bandung: PT. Remaja Rosdakarya. 